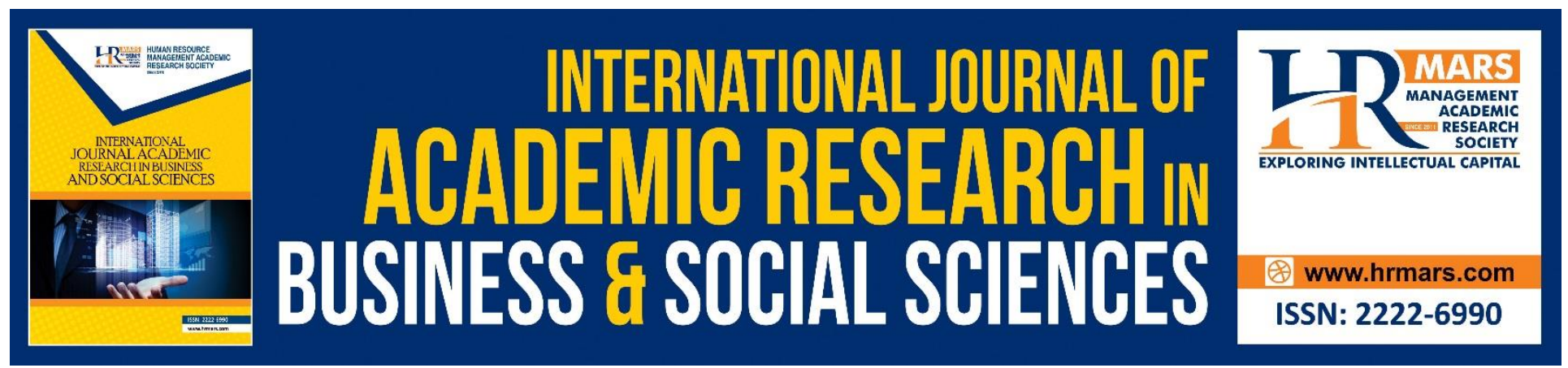

\title{
Improving Collaborative Sharing Environment in Higher Learning Institutions Using Knowledge Integration Practice
}

Noor Anida Zaria Mohd Noor, Nor Syazwani Mat Salleh, Mohd Hishamuddin Abdul Rahman \& Ismail@ Ismail Yusuf Panessai

To Link this Article: http://dx.doi.org/10.6007/IJARBSS/v10-i8/7620

DOI:10.6007/IJARBSS/v10-i8/7620

Received: 04 May 2020, Revised: 05 June 2020, Accepted: 10 July 2020

Published Online: 19 August 2020

In-Text Citation: (Noor, Salleh, Abdul Rahman, \& Panessai, 2020)

To Cite this Article: Noor, N. A. Z. M., Salleh, N. S. M., Abdul Rahman, M. H., \& Panessai, I@ I. Y. (2020). Improving Collaborative Sharing Environment in Higher Learning Institutions Using Knowledge Integration Practice. International Journal Academic Research in Business and Social Sciences. 10(8), 710-716.

Copyright: (C) 2020 The Author(s)

Published by Human Resource Management Academic Research Society (www.hrmars.com)

This article is published under the Creative Commons Attribution (CC BY 4.0) license. Anyone may reproduce, distribute, translate and create derivative works of this article (for both commercial and non-commercial purposes), subject to full attribution to the original publication and authors. The full terms of this license may be seen

at: http://creativecommons.org/licences/by/4.0/legalcode

Vol. 10, No. 8, 2020, Pg. 710 - 716

http://hrmars.com/index.php/pages/detail/IJARBSS

JOURNAL HOMEPAGE

Full Terms \& Conditions of access and use can be found at http://hrmars.com/index.php/pages/detail/publication-ethics 


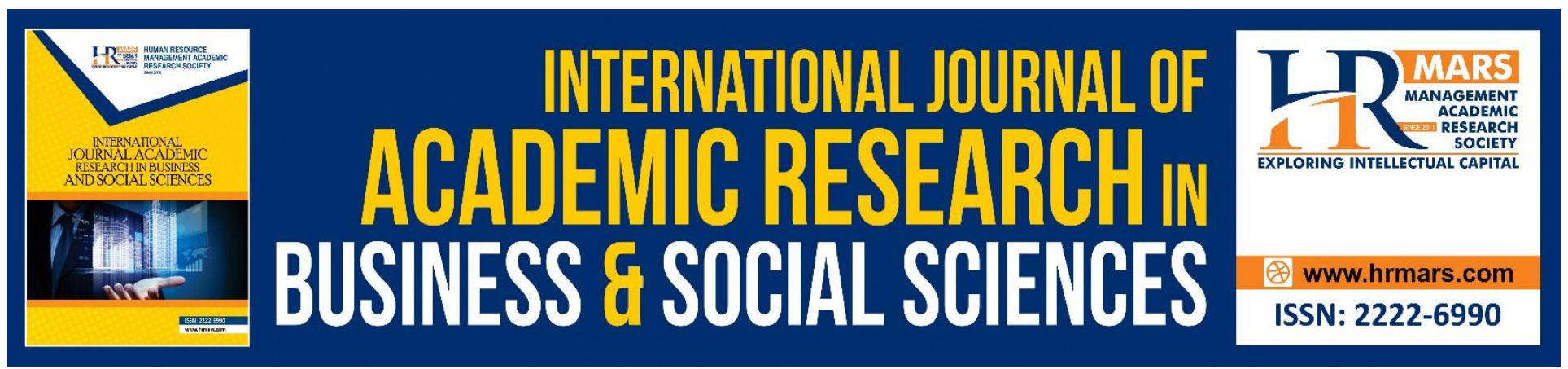

\title{
Improving Collaborative Sharing Environment in Higher Learning Institutions Using Knowledge Integration Practice
}

\section{Noor Anida Zaria Mohd Noor, Nor Syazwani Mat Salleh, Mohd Hishamuddin Abdul Rahman \& Ismail@ Ismail Yusuf Panessai}

Faculty of Art, Computing and Creative Industry, Universiti Pendidikan Sultan Idris (UPSI), Malaysia Email: ${ }^{1}$ anidazaria@fskik.upsi.edu.my, ${ }^{2}$ syazwani.ms@fskik.upsi.edu.my,

3mhishamuddin@fskik.upsi.edu.my, 4ismailyusuf@fskik.upsi.edu.my

\begin{abstract}
Knowledge integration promotes the integration of member's specialized knowledge at the team level and it also educates members on how to leverage other member's expertise. However, there is almost no research on how knowledge integration practice can improve collaborative sharing environment in higher learning institutions. Therefore, the purpose of this paper to examine the practice of knowledge integration among higher learning institution students in improving collaborative sharing environment. This paper undertakes quantitative methodology where the data is collected from 196 students who are taking entrepreneurship subject at their final year of study using questionnaire and then analyze using SPSS software. The result from this study shows that the learners have successfully practicing knowledge integration process in improving collaborative sharing environment in order to exchange knowledge and resources in an optimal way. This paper reveals that the practicing of knowledge integration has reduce the knowledge creation period through socialization process among the learners.
\end{abstract}

Keywords: Knowledge Integration, Collaborative Sharing Environment, Socialization.

\section{Introduction}

Knowledge is about the understanding that is acquired through personal experience and the information gathered regarding factual information. It is always considered as the most important aspect in human life (Noor, 2018; Syed-Ikhsan and Rowland, 2004). Knowledge comes as a person uses information and combines knowledge with his/her experience, the knowledge is then shared and transferred from one person to another, where it is eventually combined and create new knowledge. The process of transferring and combining knowledge is known as knowledge integration $(\mathrm{KI})$.

Noor (2012) quoted that Hsi (1997) claimed that the knowledge integration is supported by social factors such as peer interaction, collaborative discourse and social norms so that knowledge 
INTERNATIONAL JOURNAL OF ACADEMIC RESEARCH IN BUSINESS AND SOCIAL SCIENCES

Vol. 10 , No. 8, 2020, E-ISSN: 2222-6990 @ 2020 HRMARS

integration can facilitate the building process by minimizing the interaction restriction in the learning process. Therefore, this study intent to focus on important of promoting knowledge integration in the learning process among the learners.

\section{Knowledge Integration Practice}

Grant (1996), who is one of the earliest people who studied about knowledge integration proposed that knowledge integration to be seen as the primary role of the organization. Different authors have been exploring and describing the issues of knowledge integration in different terms for different purpose. For example, Huang and Newell (2003) describe knowledge integration as

"An on-going collective process of constructing, articulating and refining shared beliefs through social interaction of organizational members. It is also the activities that organizations use in accessing, leveraging and maintaining knowledge for the benefits of project implementation".

(Source: Huang and Newell, 2003)

For a suitable knowledge integration strategy, Badii and Sharif (2003) suggest that an organization requires a systematic approach so that it can handle the complexity and uncertainty in the daily operations. This approach suggests for the ability to model and manage the re-configurability of knowledge collection and integration structure in operations. It must also be able to accomplish quality assurance in achieving information integration for efficient decision making. This implies that knowledge integration must facilitate reflection and dialogue to allow personal and organizational learning and innovation.

\section{Collaborative Sharing Environment}

Collaboration among team members is the degree to which learners collaborate to learn, transfer knowledge and make decisions among themselves. collaboration and interaction between them may generates synergies for obtaining competitive advantage (Aragon_Correa, Martin-Tapia \& HurtadoTorres, 2013; Edmondson, 2008).

\section{Research Objectives}

- To identify the awareness about the importance of knowledge integration practice among students in higher learning institution.

- To identify the factors that influence knowledge integration practice in imptoving collaborative sharing environment.

\section{Methodology}

\section{Sample and data collection method}

The data were collected using face-to-face distribution to 196 students who are taking entrepreneurship subject. A 5-point Likert scale ranging from 1 (strongly disagree) to 5 (strongly agree) was used to indicate the respondents' answer. Each item was counted according to their percentages and mean score and recorded using the SPSS software. 
INTERNATIONAL JOURNAL OF ACADEMIC RESEARCH IN BUSINESS AND SOCIAL SCIENCES

Vol. 10, No. 8, 2020, E-ISSN: 2222-6990 @ 2020 HRMARS

\section{Instrumentation}

A questionnaire about the promoting knowledge integration was adopted from previous study by Noor (2012). Adjustment on some items were made as to suite the language competency of the sample. The questionnaire for this study is divided into two different sections, which comprises of: Section A: question in this section related to students' demographic data such as gender, age and current year of study, while Section B: question in this section is designed to obtain information and also to investigate how the student implement knowledge integration in their learning process.

\section{Finding \& Discussion}

\section{Reliability analysis}

According to Pavot, Diener, Colvin and Sandvik (1991), the satisfaction with Life Scale has good internal consistency, with a Cronbach's alpha coefficient reported of 0.85 . In this study, as shown in table 1 , the reliability test is 0.906 , which indicates satisfactory.

Table 1. Reliability Statistics

\begin{tabular}{|r|r|r|r|}
\hline $\begin{array}{c}\text { Cronbach's } \\
\text { Alpha }\end{array}$ & $\begin{array}{c}\text { Cronbach's Alpha Based on } \\
\text { Standardized Items }\end{array}$ & N of Items & Comments \\
\hline 0.906 & 0.906 & 20 & Satisfactory \\
\hline
\end{tabular}

\section{Descriptive statistics \& analysis}

The findings from Table 2 showed that the distribution of gender was higher for females with a total of 130 female respondents (66.33\%). On the other hand, there were 66 male respondents or 33.67 percent out of the total respondents. This table also showed the age of the respondents, where most of the students who participate to answer the questionnaire for this study is at the age between 20 to 25 years old, $92.86 \%$ (182 respondents). Most of the student who participate in this survey is in their final year study, where the table showed that $71.4 \%$ (140 respondents).

Table 2. Descriptive analysis

\begin{tabular}{lll}
\hline Questions & Frequency & Percent \\
\hline Gender & & \\
Female & 130 & 66.3 \\
Male & 66 & 33.7 \\
& & \\
Age & & \\
Less than 20 & 3 & 1.5 \\
20 to 25 & 182 & 92.9 \\
26 to 29 & 9 & 4.6 \\
Above 30 & 2 & 1.0 \\
& & \\
Current year of study & & \\
$1^{\text {st }}$ year & 0 & 0.0 \\
$2^{\text {nd }}$ year & 20 & 10.2 \\
$3^{\text {rd }}$ year & 36 & 18.4 \\
$4^{\text {th }}$ year & 140 & 71.4 \\
More than year 4 & 0 & 0.0 \\
\hline
\end{tabular}


INTERNATIONAL JOURNAL OF ACADEMIC RESEARCH IN BUSINESS AND SOCIAL SCIENCES Vol. 10, No. 8, 2020, E-ISSN: 2222-6990 @ 2020 HRMARS

\section{Knowledge Integration Practice}

Table 3 shows the three questions that have been used to identify how the learners know about the specialized knowledge that their learning peers have. The results for the three question shows the percentage or agree and strongly agree is higher compare to strongly disagree, disagree and neutral. This shows that the learners are aware that the knowledge for each individual is unique and can be acquired through personal experience of each individual, they also know that it is important to leverage the knowledge that their learning peers have because knowledge is always considering as the most important aspect in human life as stated by Noor (2012).

Table 3. Specialized Knowledge

\begin{tabular}{|c|c|c|c|c|c|}
\hline Item & $\begin{array}{l}\text { Strongly } \\
\text { Disagree } \\
\%\end{array}$ & $\begin{array}{l}\text { Disagree } \\
\%\end{array}$ & $\begin{array}{l}\text { Neutral } \\
\%\end{array}$ & $\begin{array}{l}\text { Agree } \\
\%\end{array}$ & $\begin{array}{l}\text { Strongly } \\
\text { Agree } \\
\%\end{array}$ \\
\hline $\begin{array}{l}\text { I am fully benefits from my course } \\
\text { mate's expertise }\end{array}$ & 0.0 & 1.5 & 26.5 & 57.7 & 14.3 \\
\hline $\begin{array}{l}\text { I am successfully leverage my course } \\
\text { mate's expertise }\end{array}$ & 0.0 & 1.0 & 31.1 & 56.1 & 11.7 \\
\hline $\begin{array}{l}\text { I know which of my friends have } \\
\text { expertise in specific area }\end{array}$ & 0.0 & 3.1 & 18.4 & 62.2 & 16.3 \\
\hline $\begin{array}{l}\text { I post information about the status of } \\
\text { my tasks }\end{array}$ & 0.5 & 8.7 & 34.2 & 47.4 & 9.2 \\
\hline $\begin{array}{l}\text { I exchange task-related information } \\
\text { with my course mates }\end{array}$ & 1.5 & 3.1 & 19.9 & 61.7 & 13.8 \\
\hline $\begin{array}{l}\text { I ask my course mate for tips and advice } \\
\text { about problems that I face }\end{array}$ & 0.5 & 2.0 & 18.4 & 50.0 & 29.1 \\
\hline $\begin{array}{l}\text { I provide comments and received } \\
\text { feedback from my course mates }\end{array}$ & 0.0 & 2.6 & 19.4 & 57.1 & 20.9 \\
\hline $\begin{array}{l}\text { I share thoughts and opinion with my } \\
\text { course mates about issues related to } \\
\text { our study }\end{array}$ & 0.0 & 3.1 & 13.3 & 60.7 & 23.0 \\
\hline $\begin{array}{l}\text { I spontaneously contact my course } \\
\text { mates for exchange task-relevant } \\
\text { information and knowledge }\end{array}$ & 1.0 & 3.0 & 27.0 & 51.5 & 18.4 \\
\hline $\begin{array}{l}\text { I always validate aspects of my study } \\
\text { with my course mates }\end{array}$ & 1.0 & 2.0 & 28.6 & 57.1 & 11.2 \\
\hline $\begin{array}{l}\text { I discuss issues of the task with two or } \\
\text { more friends simultaneously }\end{array}$ & 1.0 & 4.1 & 21.4 & 58.2 & 15.3 \\
\hline $\begin{array}{l}\text { I build consensus with my course mates } \\
\text { about important task-related issues } \\
\text { faced }\end{array}$ & 0.5 & 2.0 & 20.4 & 66.3 & 10.7 \\
\hline $\begin{array}{l}\text { I support joint discussion decision } \\
\text { making and collective problem solving } \\
\text { with my course mates }\end{array}$ & 0.0 & 3.6 & 18.9 & 56.1 & 21.4 \\
\hline
\end{tabular}


INTERNATIONAL JOURNAL OF ACADEMIC RESEARCH IN BUSINESS AND SOCIAL SCIENCES Vol. 10, No. 8, 2020, E-ISSN: 2222-6990 @ 2020 HRMARS

\begin{tabular}{|l|l|l|l|l|l|}
\hline $\begin{array}{l}\text { I compare and contrast idea and } \\
\text { perspective from many different people } \\
\text { with my course mates }\end{array}$ & 0.0 & 5.1 & 27.6 & 43.4 & 24.0 \\
\hline $\begin{array}{l}\text { I brainstorm idea and opinion with } \\
\text { multiple people involved in the } \\
\text { collective task }\end{array}$ & 0.5 & 4.6 & 22.4 & 52.6 & 19.9 \\
\hline $\begin{array}{l}\text { I interact with multiple course mates } \\
\text { simultaneously }\end{array}$ & 1.0 & 3.6 & 23.0 & 56.6 & 15.8 \\
\hline $\begin{array}{l}\text { People in my class have a shared } \\
\text { understanding of the collective task and } \\
\text { the way it should be accomplished }\end{array}$ & 0.5 & 2.0 & 25.5 & 59.7 & 12.2 \\
\hline $\begin{array}{l}\text { People in my class have a shared } \\
\text { understanding of the key milestone, } \\
\text { challenges and objectives that } \\
\text { characterized the collective task }\end{array}$ & 0.5 & 3.6 & 26.0 & 54.6 & 15.3 \\
\hline $\begin{array}{l}\text { People in my class have shared } \\
\text { understanding about the way task is } \\
\text { distributed amongst its members }\end{array}$ & 0.0 & 3.1 & 23.5 & 61.2 & 12.2 \\
\hline $\begin{array}{l}\text { People in my class have a good "map" } \\
\text { about others' talents and skills }\end{array}$ & 0.5 & 3.1 & 31.6 & 48.0 & 16.8 \\
\hline
\end{tabular}

\section{Conclusion and Future Recommendation}

The finding of the study shows that most of the learners are aware that by practicing knowledge integration in their learning process can improve the collaborative sharing environment in the higher learning institution where they must have considered two important factors, they are: specialized knowledge and collaborative sharing.

This study enriches the understanding about the concept of knowledge integration where it highlights the factors that influence the process of incorporating new knowledge into the body of existing knowledge.

Since this study just provide information about the knowledge integration in the context of learners in higher learning institutions, so it opens for further research related to the knowledge integration in a different perspectives such as between lecturers and learners and also new lecturers and expert lecturer. Besides that, it is also can be implement in the school environment in order to create broader perspectives.

\section{Acknowledgement}

This paper is based on the research project entitled the importance of knowledge integration process in learning among higher learning institution students towards producing pools of Malaysian knowledge workers. The authors would like to extend their gratitude to the Research Management and Innovation Centre (RMIC), Sultan Idris Education University (UPSI) for the University Research Grants (code: 2017-0299-107-01) that helped fund the research. 
INTERNATIONAL JOURNAL OF ACADEMIC RESEARCH IN BUSINESS AND SOCIAL SCIENCES Vol. 10, No. 8, 2020, E-ISSN: 2222-6990 @ 2020 HRMARS

\section{References}

Aragon-Correa, A. A., Martin-Tapia, I. \& Hurtado-Torres, N. E. (2013) Proactive environmental strategies and employee inclusion: The positive effects of information sharing and promoting collaboration and the influence of uncertainty. Organization \& Environment, 26(2), 139-161

Disessa, A. (1998). Knowledge in pieces. In G. Forman and P. Pufall, Constructivisn in the Computer Age (Hillsdale, NJ: Lawrence Erlbaum Associates), 49-70

Edmondson, A. C. (2008). The competitive imperative of learning. Harvard Business Review, 86(8-7), 60-67

Eylon, B. S., \& Linn, M. C. (1998). Learning and instruction: an examination of four research perspectives in science education. Review of Educational Research, 58(3); 251-301.

Grant, R. M. (1996). Prospering in dynamically-competitive environment: organizational capability as knowledge integration. Organization Sciences, 7(4), 375-387.

Hedges, M., \& Dunn, S. (2018). Academic crowdsourcing in humanities. Chandos Publishing. ISBN: 978-0-08-100941-3. DOI: 10.1016/C2015-0-04363-5.

Huang, J. C., \& Newell, S. (2003). Knowledge integration processes and dynamics within the context of cross-functional projects. International Journal of Project Management, 21, 167- 176.

Hsi, S. (1997). "Facilitating knowledge integration in science through electronic discussion: the multimedia forum kiosk" Ph.D. dissertation from University of California at Berkeley. (101 pages).

Linn, M. C., Disessa, A., Pea, R. D., \& Songer, N. B. (1994). Can research on science learning and instruction inform standards for science education? Journal of Science Education and Technology, 3(1), 7-15.

Linn, M. C. (2000). Designing the knowledge integration environment, International Journal of Science Education, 22(8), 780-796, DOI:10.1080/095006900412275

Linn, M. C., \& Mulienburg, L. (1996). Creating lifelong science learners: what models form a firm foundation: Educational Researcher. 25(5), 18-24.

Noor, N. A. Z. M. (2018). The influence of knowledge worker characteristics on knowledge integration capacity among Malaysian knowledge workers. The $3^{\text {rd }}$ International Conference on ICT in Education 2018 (ICTE2018).

Noor, N. A. Z. M. (2012). Factors contributing to knowledge integration. (Unpublished Ph.D. dissertation). Universiti Utara Malaysia, Kedah, Malaysia.

Pavot, W., Diener, E., Colvin, C. R., \& Sandvik, E. (1991).Further validation of the satisfaction with lofe scale: Evidence for the cross method convergence of well-being measures. Journal of Personality Assessment, 57, 149-161.

Syed-Ikhsan, S. O. S., \& Rowland, F. (2004). Benchmarking knowledge management in a public organization in Malaysia. Benchmarking. An International Journal, 11 (3), 238-266. 